\title{
Aesthetic Judgements and Motivation
}

Abstract: Are aesthetic judgements cognitive, belief-like states or non-cognitive, desirelike states? There have been a number of attempts in recent years to evaluate the plausibility of a non-cognitivist theory of aesthetic judgements. These attempts borrow heavily from Non-cognitivism in metaethics. One argument that is used to support metaethical Non-cognitivism is the argument from Motivational Judgement Internalism. It is claimed that accepting this view, together with a plausible theory of motivation, pushes us towards accepting Non-cognitivism. A tempting option, then, for those wishing to defend Aesthetic Non-cognitivism, would be to appeal to a similar argument. However, both Caj Strandberg and Walter Sinnott-Armstong have argued that Internalism is a less plausible claim to make about aesthetic judgements than about moral judgements by raising objections against Aesthetic Internalism. In this paper I will argue that both of these objections can be raised against Internalism about moral judgements as well. As a result, Internalism is no less plausible a claim to make about aesthetic judgements than about moral judgements. I will then show how a theory of Internalism about normative judgements in general is capable of avoiding both of these objections.

\section{Keywords: AESTHETICS; MOTIVATIONAL JUDGEMENT INTERNALISM;} METAETHICS; AESTHETIC JUDGEMENT;

\section{Introduction}

Are aesthetic judgements cognitive, belief-like states or non-cognitive, desire-like states? In recent years a number of aestheticians, inspired by the debate between cognitivists and non-cognitivists about moral judgements, have attempted to provide answers to these questions (See Hopkins [2001]; Todd [2004] and McGonigal [2006]). These answers have 
often been informed in interesting ways by the equivalent debates in metaethics ${ }^{1}$, and can be seen as part of the more general project of investigating whether theories about moral judgements can be plausibly applied to other normative judgements (see, for example, the following defences of epistemic Non-Cognitivism Gibbard (2003 p.227), Chrisman (2007) and Ridge (2007). The fact that aestheticians have looked to metaethicists for inspiration should come as no surprise, given that it is commonly suggested that aesthetic judgements and moral judgements share a similar structure (eg. Ayer [1936], Mackie [1977], McDowell [1983] and McNaughton [1988]). The focus of this paper will not be on whether Cognitivism or Non-cognitivism provides the more plausible theory of aesthetic judgements. Instead I will be investigating the related question of whether there is a necessary connection between aesthetic judgements and motivation. This question is importantly related to the previous one, as it is often claimed in metaethics that the existence of a necessary connection between moral judgements and motivation provides support for metaethical Non-cognitivism (eg. Shafer-Landau [2003 p.121], Hare [1952 pp. 79 -93], and Stevenson [1937]).

The possibility of a necessary connection between aesthetic judgements and motivation has been recently dismissed by both Caj Stranberg (2011) and Walter Sinnot-Armstrong (2010). Both Stranberg and Sinnot-Armstrong claim that it is much less plausible to think that a necessary connection exists between aesthetic judgements and motivation than to think that such a connection holds for moral judgements. If true this would provide us with good reason to think that there is an important difference between moral

\footnotetext{
${ }^{1}$ Todd (2004), for example, defends a view similar to Blackburn's view (1998) about moral judgements.

${ }^{2}$ Although, for all this argument shows, moral judgements could include both cognitive and non-cognitive states. Such hybrid views are increasingly popular, see, for example, Ridge (2014) and Tresan (2006).

${ }^{3}$ This way of characterizing the appeal of Internalism comes from Strandberg (2012 p.89).

${ }^{4}$ Smith (1994 p.61) restricts Internalism to rational agents. Dreier (1990 p.14) restricts Internalism to normal agents. Miller (2008) considers a form of Internalism restricted to virtuous agents. 2

${ }^{5}$ Miller makes this point convincingly about versions of Internalism that are restricted to
} 


\section{Forthcoming in Inquiry}

judgements and aesthetic judgements. In this paper I will respond to Strandberg and Sinnott-Armstrong by arguing that both objections can be raised against the existence of the necessary connection for moral judgements as well. As a result, neither claim gives us good reason to think that aesthetic judgements are different from moral judgements. I will then provide an account of the necessary connection between normative judgements and motivation that avoids these objections.

\section{Motivational Judgement Internalism in Metaethics}

Motivational Judgment Internalism, henceforth 'Internalism', in metaethics is the view that there is a necessary connection between moral judgements and motivation. This claim plays an important role in metaethical debates. The reason for this is that it seems possible to argue from Internalism and the dominant theory of motivation to the conclusion that moral judgements are non-cognitive states (Smith [1994]). The Humean Theory of Motivation states that beliefs by themselves are incapable of motivating. If we accept Internalism about moral judgements then we accept that motivation is necessarily connected to moral judgements and so according to the Humean view of motivation, they cannot be purely cognitive states. ${ }^{2}$

Many have found Internalism to be an attractive theory of moral judgements because it provides an explanation for the strong connection that seems to exist between moral language and motivation. ${ }^{3}$ As many have observed, there seems to be something odd about someone who claims that an act is obligatory but fails to be motivated to perform it (those who make this claim include: Dancy [1993 p.4], Dreier [1990 pp.13-14], Smith [1994 p.60], Blackburn [1998 pp.48, 52-53] and Stevenson [1944 pp.16-17]). We can see

\footnotetext{
${ }^{2}$ Although, for all this argument shows, moral judgements could include both cognitive and non-cognitive states. Such hybrid views are increasingly popular, see, for example, Ridge (2014) and Tresan (2006).

${ }^{3}$ This way of characterizing the appeal of Internalism comes from Strandberg (2012 p.89).
} 


\section{Forthcoming in Inquiry}

the plausibility of this claim by considering the following case given by Michael Smith (1994 p.6):

Case 1: Jill and Jane are debating whether or not to donate money to famine relief. Jane says that they both ought to make a donation. A charity worker calls by, asking for donations and Jane refuses to donate.

Jane's behaviour seems puzzling in this case. We expect Jane's moral judgement that she ought to donate money to motivate her to do so. Internalism provides a ready explanation for this intuition; the reason this case is puzzling is explained by the necessary connection that exists between moral judgements and motivation.

The other important argument in the debate supports externalism. This argument concerns the conceptual possibility of the amoralist, someone who makes sincere moral judgments but remains unmotivated by them. Externalists claim that such people are at least conceptually possible (eg. Svavarsdóttir [1999]). If we accept this then we seem forced to accept that there is no necessary connection between moral judgments and motivation. Internalists respond to the possibility of amoralists by weakening their claim. Either by claiming that the motivation need only be pro tanto or by restricting the claim to certain kinds of moral agents (rational, normal or virtuous). ${ }^{4}$ Of course, by doing so internalists run the risk of decreasing the significance of the theory for other metaethical debates. Certainly for some ways of restricting Internalism it seems reasonable to worry that what started as an interesting claim about moral judgements, has become a less interesting (for metaethicists at least) claim about certain kinds of moral agent. ${ }^{5}$

\footnotetext{
${ }^{4}$ Smith (1994 p.61) restricts Internalism to rational agents. Dreier (1990 p.14) restricts Internalism to normal agents. Miller (2008) considers a form of Internalism restricted to virtuous agents.

${ }^{5}$ Miller makes this point convincingly about versions of Internalism that are restricted to virtuous agents. This, Miller points out, "Might be the case simply because of what it is to be a 'virtuous agent' in the first place," (2008 p.252).
} 


\section{Forthcoming in Inquiry}

Nevertheless, my primary interest in this paper is not the implications of Internalism but whether it is a plausible claim to make about aesthetic judgements. For the purposes of this paper I will be dealing with the following weak version of Internalism:

Moral Motivational Judgement Internalism (Moral Internalism): For rational agents, there is a necessary connection between making a moral judgement and being motivated to act in line with that judgement. ${ }^{6}$

In the remainder of this paper I will investigate whether a similar claim can be made about aesthetic judgements. As with moral judgements, the truth or falsity of Internalism about aesthetic judgements would have important consequences for the debate about the nature of these judgements. If Internalism about such judgements is plausible then this may provide support for non-cognitivists about aesthetic judgements.

\section{Aesthetic Motivational Judgement Internalism}

In this section I will look at what an aesthetic version of Internalism would look like. The first step in giving an account of Internalism about some type of judgement is to determine the actions that these judgements motivate us to perform. This is harder to do for aesthetic judgements than for moral judgements. A central class of moral judgements concerns the performance of certain kinds of action. When I judge that I morally ought to $\phi$ it is quite clear what action this judgement should motivate me to perform if internalism is true. Insofar as I am rational, this judgement should motivate me to $\phi$. However, it is less clear what actions I might be motivated to perform when I judge a work of art to be beautiful. As this judgement is not about an action it is harder to see what action it might motivate me to perform.

\footnotetext{
${ }^{6}$ This is similar to versions of internalism endorsed by Smith (1994) and Van Roojen (2010).
} 


\section{Forthcoming in Inquiry}

Nevertheless, as Strandberg (2011 p.53) points out, there does seem to be some kind of connection between aesthetic judgements and motivation. We assume that someone who recognises the aesthetic value of a work of art will be motivated to seek out similar works of art, at least so long as she is aesthetically competent.

To see this consider the following case:

Case 2: Alex says that The Ring Cycle possesses a very high degree of aesthetic value. However, Alex is never motivated to go to other operas by Wagner. Whenever one of Wagner's operas is on in his town Alex goes to see the latest Hollywood blockbuster at the multiplex instead.

There seems to be something puzzling about Alex's behaviour, we want to say that Alex is being either irrational or lacking in aesthetic competence. The fact that this seems puzzling is instructive. There seems to be a reliable connection between judging a work of art to be aesthetically good and being motivated to seek out similar works of art. This reliable connection provides prima facie support for the existence of an internal connection between aesthetic judgements and motivation.

While Strandberg considers only positive aesthetic judgements, the connection seems even more plausible when we consider negative aesthetic judgements. Consider the following case:

Case 3: Rowena says that she judges the taste of mayonnaise to be aesthetically bad. Yet she regularly puts mayonnaise on her sandwiches and her chips.

Rowena's actions seem even more puzzling than Alex's. Again we would want to say that she is behaving irrationally or that she is lacking in aesthetic competence. We want to say that if she really judges the taste of mayonnaise to be aesthetically negative then she would be motivated to avoid experiencing it. 
We can formalise this form of Aesthetic Internalism in the following way:

Aesthetic Motivational Judgement Internalism (Aesthetic Internalism): For rational and aesthetically competent agents, there is a necessary connection between judging an aesthetic experience positively and being motivated to seek out similar aesthetic experiences. There is also a necessary connection between judging an aesthetic experience negatively and being motivated to avoid similar experiences. ${ }^{7}$

In this section I have looked at the form of Internalism about aesthetic judgements considered by both Strandberg. In the next section I will examine some criticisms that have been raised against the possibility of a necessary connection between aesthetic judgements and motivation.

\section{Challenges to Aesthetic Internalism}

In this section I will consider three reasons that support the claim that Aesthetic Internalism is less plausible than Moral Internalism.

Despite suggesting the form of Aesthetic Internalism we looked at in the last section, Strandberg thinks there is good reason to think that this form Internalism is less plausible than Moral Internalism. Strandberg argues that the reliable connection that exists between aesthetic judgements and motivation seems much weaker than the corresponding connection for moral judgements. He supports this claim in the following way,

\footnotetext{
${ }^{7}$ Strandberg restricts his discussion of aesthetic internalism to the link between aesthetic judgements of work of art and motivation. However, if we accept that our aesthetic judgements are not limited to aesthetic judgements of artworks then we have good reason to formulate this view without making specific reference to works of art. For the importance of aesthetic experiences that do not concern art works see Budd (2002) and Saito (2007). Thanks to an anonymous referee for helpful discussion here.
} 
It is not difficult to imagine a person who recognizes that a work of art is aesthetically good, but is not motivated to look out for similar works as he has become tired of the kind of sensation they give him or for some other reason (2011 p.53).

In other words, cases where the connection between judgements of aesthetic value and motivation break down are surprising and call for an explanation. However, cases where the equivalent connection breaks down for moral judgements seem far more surprising and have fewer acceptable explanations. While feeling tired or not being in the mood will serve as suitable explanations for not being motivated by aesthetic judgements, the same does not seem true for moral judgements. Strandberg's point seems well supported by our intuitive reactions to Case 1 and Case 2. I take it most people would share the thought that while Alex's behaviour is odd it is far less odd than Jane's. Similarly, while tiredness can explain Alex's lack of motivation to see an opera, it will not explain Jane's refusal to donate money to charity. The reason that this weaker connection creates a problem for Aesthetic Internalism is that a considerable part of the appeal of Moral Internalism is derived from the reliable connection that exists between moral judgements and motivation. If we accept that the reliable connection to motivation is weaker for aesthetic judgements than for moral judgements then we should accept that the case in favour of Internalism for aesthetic judgements is also weaker.

Walter Sinnott-Armstrong raises a similar challenge to Aesthetic Internalism. His objection is as follows: "( $\mathrm{I}) \mathrm{t}$ is not clear why I cannot judge that a modern painting (or piece of music) has the positive aesthetic quality of being creative, even though I have no desire at all to see it (or hear it played),"(2010 p.65). The point Sinnott-Armstong is making is that we can make positive aesthetic judgements for which no explanation is needed for a lack of accompanying motivation. Although this point is similar to the 
previous one, there is an important difference. Strandberg's point was that the connection between aesthetic judgements and motivation is weak enough to be broken by tiredness or some other factor that would not be sufficient to break the connection with moral judgements. Sinnot-Armstrong, on the other hand, points to a positive aesthetic judgement for which there appears to be no need whatsoever to explain a lack of accompanying motivation. This point also seems well supported by our intuitions. We would find Alex's behaviour much more understandable if he judged opera to be the most creative art form rather than the best. This is problematic for Aesthetic Internalism as it shows that it is possible to make a positive aesthetic judgement about a work of art and feel no motivation whatsoever to seek out similar art works.

The final challenge that I will consider to Aesthetic Internalism is one that can be developed from observations made by Matthew Kieran to support a criticism of an entirely different claim made about aesthetic judgements. While attacking the view that aesthetic facts are determined by the tastes of ideal aesthetic appreciators Kieran claims that cultivating certain characteristics is essential for the enjoyment of certain aesthetic experiences (2008 p.278). ${ }^{8}$ Someone who has spent a lot of time and effort developing the right capacities to appreciate classical music may find it hard to appreciate disco. If we spend our time developing the appropriate character traits and responses for enjoying horror films we might find it hard to appreciate realist cinema.

To link this back to the discussion of motivation we can imagine someone who used to have all of the appropriate character traits to appreciate horror films gradually becoming more and more interested in realist cinema. Perhaps she has begun spending time with

\footnotetext{
${ }^{8}$ The claim that aesthetic facts are determined by the tastes of ideal critics is a view that is often thought to found in David Hume (1963), although Stephanie Ross argues that this is not how Hume's position should be understood (2008).
} 


\section{Forthcoming in Inquiry}

people who enjoy these films and this has allowed her to develop an appreciation for the slower pace of realist cinema. As she has developed these traits her capacity to appreciate horror films has deteriorated. She no longer gets the same enjoyment from horror films that she once did and as a result she is no longer motivated to watch these films. The reason this is important for our discussion is that we can imagine a person meeting this description who continues to judge horror films to possess great aesthetic value. If we accept that such a person is possible then we have a case of someone who judges that horror films are aesthetically valuable but feels no motivation whatsoever to watch any.

\section{Extending the Challenges to Moral Internalism}

In this section I will respond to the three problems for Aesthetic Internalism looked at in the last section. I will argue that while the three objections present major problems for the form of Aesthetic Internalism we have looked at up to now, they would equally apply to a similarly formulated version of Moral Internalism. These problems, then, do not show that Aesthetic Internalism is less plausible than Moral Internalism. The definition of Aesthetic Internalism given in $\$ 2$ looked to aesthetic judgements that are not clearly connected with any specific action on the part of the appraiser. Recognising the aesthetic value of an artwork does not commit the appraiser to any specific act, though as we saw in $§ 2$, being left completely unmoved by such a judgement may seem odd. The claim I will make in this section is that, once we appreciate exactly what Moral Internalism is committed to, these objections can equally be raised against this view.

To start, let's note that Moral Internalism is a claim about all moral judgements. If this claim is true then we should expect all positive moral judgements to motivate us to act in line with them. 


\section{Forthcoming in Inquiry}

The first reason we looked at to think that Aesthetic Internalism is less plausible than Moral Internalism is that there are some aesthetic judgements for which a lack of motivation requires little explanation. Strandberg claims that this is the case with judgements of aesthetic value. A lack of accompanying motivation for such judgements can easily be explained by the agent being tired or not in the right mood. However, the same point can be made against Moral Internalism. We can judge an act to be morally good and require very little explanation for a lack of accompanying motivation. In fact the very same explanation that Strandberg considered in the aesthetic case will apply here. We can imagine someone who has spent ten years helping out at a soup kitchen and has become so tired of acting in this way that she has no motivation to carry on. There does not seem to be any reason to describe such a person as irrational. The crucial part of this objection is that the act is judged to be morally good rather than morally obligatory. This is important, as the claim that we might be unmotivated by a judgement that an act is morally good is much more plausible when we are clear that this not the same as judging the act to be morally obligatory. Similarly, there can be acts that I judge to be morally good that due to tiredness or not being in the right mood, I feel no motivation to perform. ${ }^{9}$

Keeping in mind the separation of the good and the obligatory also allows us to respond to the second argument for the claim that Aesthetic Internalism is less plausible than Moral Internalism. The claim that there are some positive aesthetic judgements for which there is no need to explain the lack of an accompanying motivation will apply to moral judgements as well. Judging an act to be supererogatory (beyond the call of duty) seems to be just such a judgement. I take it that it's a familiar feature of our everyday experience

\footnotetext{
${ }^{9}$ Zangwill (2008) makes a similar point about moral judgements and tiredness without noticing the importance of the distinction between the morally good and the morally obligatory.
} 
that we are not always motivated by these judgements, nor do we expect others to be. ${ }^{10} \mathrm{I}$ judge that it would be supererogatory for me to stop working on this paper and go to help out at a soup kitchen. However, I have no motivation to do so and this strikes me as both perfectly normal and perfectly rational. There seems little need for someone to explain why she is not motivated to perform an act she judges to be supererogatory. A reasonable response to someone puzzled as to why an agent is unmotivated by a supererogation judgement is to point out that it was judged to be supererogatory not obligatory. Sinnott-Armstrong's point that there are some aesthetic judgements for which there is no need to explain the lack of accompanying motivation applies equally to Moral Internalism.

Perhaps, though, there is another way of understanding Sinnott-Armstrong's point that presents a different problem. The example Sinnott-Armstrong gives, a judgement that a work of art is creative, is a thick aesthetic judgement. A thick judgement is one that contains both descriptive and evaluative elements. ${ }^{11}$ Perhaps, then, we might understand Sinnott-Armstong as pointing to a lack of connection between thick aesthetic judgements and motivation that does not apply to thick ethical judgements. However, this response does not withstand serious scrutiny, as thick ethical judgements do not clearly show a link to motivation either. For example, someone might judge that it would be courageous to volunteer to assist in the clearing of landmines but feel no motivation to do so. Such a person does not seem guilty of any form of irrationality.

\footnotetext{
${ }^{10}$ For a full defence of the view that supererogation judgements are not necessarily connected to motivation see Archer (2016).

${ }^{11}$ Williams introduces the idea of thick ethical terms to describe terms such as 'brave' and 'prudence' that contain both evaluative and descriptive elements (1985 p.129). For a discussion of thick aesthetic concepts see Bonzon (2009).
} 
To make the point more forceful, someone can judge an act to be courageous even though it is morally bad. ${ }^{12}$ We might think that suicide bombers display courage in giving up their lives for their cause while judging that their acts are overall morally bad. Someone who judged that it would take courage for her to become a suicide bomber but that it would be morally bad to do so would clearly not be irrational if she was completely unmotivated to become a suicide bomber. We can see, then, that SinnottArmstrong's criticism of Aesthetic Internalism also applies to thick moral judgements. A tempting line of response to both of these problems is to point out that Moral Internalism is only intended as a pro tanto claim. This means that positive moral judgements must motivate to some extent but that this motivation can be overridden by other concerns. This would allow the internalist to say that in order to be rational people must be motivated to some extent by a judgement that an act is supererogatory or courageous but that this motivation can be overridden. While this line of response is tempting it is not a plausible view of Internalism. To see why consider a case where someone is choosing between two permissible moral acts one of which is much better than the other. On this pro tanto form of Internalism the agent should be motivated to some extent to perform the less valuable option. This, though, is implausible. While it is possible that such an agent might be motivated to some extent by such a judgement

\footnotetext{
${ }^{12}$ We might object that if we accept the unity of the virtues, according to which the possessor of one virtue must possess them all (See Aristotle Nicomachean Ethics 1145 a12 ), then we could not make such a judgement. However, not everyone accepts such a view, meaning that they, at least, could judge an act to be courageous and morally bad. Even those who accept some weak version of the view could make this judgement. For example, Susan Wolf supports the view that, "to have one virtue, one must have the knowledge required for the possession of the others,"(2007 p.161). Holding this view is perfectly compatible with judging that an act can be courageous and morally bad. Finally, while it may be the case that a supporter of the strongest form of the unity of the virtues (eg. Toner (2014)) could not judge an act to be courageous and morally bad, such a person should nevertheless accept my previous point that someone could judge the clearing of landmines to be courageous without being motivated to clear landmines. Thanks to an anonymous referee for helpful discussion here.
} 
there seems nothing odd or incoherent about someone who made this judgement of the balance of reasons and had no motivation whatsoever to perform the less valuable act. ${ }^{13}$ To see why consider the following case:

Children vs. Donkeys: John has five pounds he has set aside to donate to a charity. He judges that he has some moral reason to donate it to a charity that cares for donkeys but much stronger reason to donate it to a charity that feeds starving children. He also judges that either act would be morally good but not morally required.

In this case John judges he has some moral reason to perform one act but much greater reason to perform another. There seems no reason to think that it would be irrational for John to be completely unmotivated to donate his money to the donkey charity in this case. $^{14}$

Finally, the point that we might judge an aesthetic experience to be valuable but be unmotivated to perform it due to having developed traits that are unsuited to the appreciation of those experiences can also be transferred to moral judgements. It seems reasonable to think that focussing on developing the traits needed to be a war hero will be quite different from those needed to work in a soup kitchen. Just as developing a love of realist cinema might make me unsuited to appreciating horror films, developing the virtue of courage might make me unsuited to performing acts of charity. It seems perfectly reasonable to imagine a war hero who judges helping out at a soup kitchen to be a charitable act but has no motivation to act in this way. Again, the important point here is that these acts are judged to be good rather than obligatory. While it may be puzzling for a war hero to judge that helping out at a soup kitchen would be obligatory

\footnotetext{
${ }^{13}$ Similar points are made by Dancy (2004 p.17), Wallace (2006 pp. 187-188) and Strandberg (2013 p.32).

${ }^{14}$ I have made this point before in Archer (2016 p. 609).
} 


\section{Forthcoming in Inquiry}

and be unmotivated by this judgement, the puzzle disappears when the case is altered so that the judgement is one of moral goodness or some other positive moral judgement.

In this section, I have responded to three reasons to think that Aesthetic Internalism is a less plausible claim than Moral Internalism. I have argued that when we appreciate the range of moral evaluations that Moral Internalism applies to then these can be raised with equal force against this form of Internalism. There is no reason, then, to think that Aesthetic Internalism is less plausible than Moral Internalism.

\section{Saving Motivational Judgement Internalism?}

In this section I will suggest a way in which both Aesthetic Internalism and Moral Internalism can be saved from the three objections I have considered so far. I will argue that restricting the claims to first person judgements about what there is most reason to do, all things considered, can save a limited form of both views.

What the three objections considered in the last two sections amount to is that there are certain kinds of judgements we make in morality and aesthetics that are not clearly linked to motivation. Judgments about goodness and thick judgements are not necessarily accompanied by motivation, even among the rational. This should not surprise us. The reason that these judgements are not necessarily linked to motivation is not because they are aesthetic or moral judgements but because they are not sufficiently action guiding. Judging an act to be aesthetically or morally good may be accompanied by a judgement that these acts are bad in some other way. An act that is morally good may be prudentially bad. An act that is aesthetically good may be morally wrong. Similarly thick judgements and judgements about the virtues are also insufficiently action guiding to be necessarily linked to motivation. 
What this tells us is that in order to find a plausible version of Motivational Internalism we must ask ourselves what kind of judgements will be necessarily connected to motivation among rational agents. The answer is that a rational agent will necessarily be motivated by a judgement that an act is what she has most reason, all things considered, to do. ${ }^{15}$ This form of Internalism concerns only all things considered normative judgements. It can be defined as follows:

Normative Motivational Judgement Internalism (Normative Internalism): For rational agents, there is a necessary connection between first personal judgements about what there is, all things considered, most normative reason to do and motivation. ${ }^{16}$

This form of internalism allows us to see why there seems to be a necessary connection between some aesthetic judgements and motivation. If I judge that I ought to paint my room blue rather than black and this judgement coincides with what I have all things considered most reason to do then I will necessarily be motivated to paint the room blue if I am rational. It also explains why the objections to both Aesthetic Internalism and Moral Internalism were successful. The criticisms presented us with cases where an agent is unmotivated by an aesthetic or moral judgement that is not also an all things considered normative judgement. This is perfectly compatible with Normative Internalism.

If we accept Normative Internalism, then we should accept that Aesthetic Internalism and Moral Internalism are on a par with each other. Both kinds of judgement contribute to our all things considered judgement about what we ought to do and both will be necessarily connected to motivation whenever these judgements coincide with our

\footnotetext{
${ }^{15}$ Wedgwood makes this point (2007 p.23-26). Sinnott-Armstrong also thinks that internalism should be restricted to all things considered practical judgements, though he denies that aesthetic judgements can ever be overall practical judgements (2010 p.65). ${ }^{16}$ This is similar to the form of Internalism given by Wedgwood (2007 p.25).
} 
judgements about what we have most reason to do, all things considered. Of course, this is not quite the same as the form of Aesthetic Internalism considered in $\$ 2$. There is no reason to think that Alex was making an all things considered judgement here.

Nevertheless, it does point towards a way in which we might seek to explain the intuitive oddness of Alex's judgement. We could explain this either by explaining how aesthetic judgements weigh into our all things considered normative judgements or by explaining why aesthetic assertions such as Alex's convey an all things considered normative judgement pragmatically.

It is important to note though, that in saying that Aesthetic Internalism is on a par with Moral Internalism, I am not saying that either form of Internalism is straightforwardly true. After all, the all things considered normative judgement that I am claiming is necessarily connected to motivation is not itself an aesthetic judgement or a moral judgement. ${ }^{17}$ Rather, it is a judgement about the balance of all of the normative reasons. We might take this to mean then that there is no necessary connection between moral or aesthetic judgements and motivation. After all, it is the all things considered judgement that is necessarily connected to motivation not the moral or the aesthetic judgement. However, there is an important sense in which both moral and aesthetic judgements are connected to motivation on this account. After all, both kinds of judgement contribute to our all things considered normative judgements. The all things considered judgement just is the judgement of the balance of our aesthetic and moral reasons, together with other normative reasons such as prudential or epistemic reasons. Moreover, whenever either kind of reason is unopposed by any reasons to the contrary then, insofar as we are rational, we will form an all things considered normative judgement in line with our

${ }^{17}$ As Bernard Williams points out, while moral considerations play a role in determining what there is most reason to do, the judgement that an act is what there is most reason to do need not be a moral judgement (1985 p.19). Thanks to an anonymous referee for pressing me on this point. 


\section{Forthcoming in Inquiry}

ethical or aesthetic judgement and be motivated to act accordingly. This allows us to endorse the following form of Internalism about aesthetic and moral judgements:

Aesthetic/ Moral Internalism: Necessarily, whenever an agent makes an aesthetic or moral judgement about how to act that she does not judge to be opposed by other stronger or equally weighty normative reasons, then she will be motivated to act accordingly.

We might wonder whether this form of Internalism is able to explain why there seems to be a tighter connection to motivation for moral judgements than aesthetic judgements. However, there are several explanations that can be given for this. First, we might appeal to a view that is commonly accepted by moral philosophers. Moral Rationalism is the view that we always have most reason to act in line with our moral requirements. ${ }^{18}$ Similarly, we might hold that moral reasons override other forms of normative reason. ${ }^{19}$ If we accept either view then this will explain why Moral Internalism seems more plausible than Aesthetic Internalism. The reason it seems more plausible is that we will expect moral judgements to coincide with our all things considered judgements about what to do more often than aesthetic judgements do. ${ }^{20}$ Certainly when we consider a case where we have a clash between a moral reason and an aesthetic reason it seems reasonable to think that the moral reason should take priority (at least on most occasions). ${ }^{21}$ Take the following example, if someone is in a burning museum and is able to save either a Rembrandt painting or a museum guard it seems reasonable to think that

\footnotetext{
${ }^{18}$ Those who defend some version of this view include Portmore (2011), Smith (1994), and Van Roojen (2010). Both Smith and Van Roojen argue that Moral Internalism follows from Moral Rationalism.

${ }^{19}$ Those who defend some version of this view include Hare (1968), Stroud (1998) and Fairbanks (2012). This view is sometimes confused with Moral Rationalism. For a discussion of the difference between the two see Archer (2014).

${ }^{20}$ This seems right even if we accept the claim that aesthetic obligations exist. This claim is defended by Eaton (2008). Importantly though Eaton accepts that these obligations may be reducible to moral obligations or exist only when comparing two cases which are identical in all moral respects (2008 p.5-8).

${ }^{21}$ This point is made by Hampshire who claims that aesthetic considerations are trivial compared to moral reasons (1954 p.162).
} 
the moral requirement to save the guard should override the aesthetic reasons in favour of saving the painting. ${ }^{22}$ Of course, as Van Roojen notes, Moral Rationalism might be true without everyone being aware of its truth. If this were the case then it might not be irrational for such an agent to be unmotivated by a moral judgement. However, as Van Roojen (2010 pp.518-521), argues, the meaning of the term 'morally required' is determined by the normal cases, those where the judgement that an action is right motivates the agent. This allows us to conclude that rational agents acting normally will be motivated by a judgement that an act is morally required.

Likewise, we might think that the proportion of judgements that are first personal practical deliberation judgements is smaller in aesthetics than morality. In ethics a large proportion of the judgements that we make concern the assessment of behaviour, be it our own or that of others. We cannot escape the fact that many of the decisions that we make are open to ethical evaluation. In aesthetics, however, it seems plausible to think that the evaluation of behaviour plays a lesser role. Often we are concerned more with evaluating objects. Often these judgements have no clear practical upshot. ${ }^{23}$ Of course this may not be true for everyone. Things may be different if we approach this from the

\footnotetext{
${ }^{22}$ This case is mentioned by Eaton (2008 p.4). It is worth noting that this is not the only way of interpreting the case. We might think that in so far as there are any requirements in this case, they are moral rather than aesthetic requirements and so this is a case of a clash between two moral requirements rather than an aesthetic and a moral requirement. This way of thinking is compatible with the point I am making that moral reasons seem to take priority over aesthetic reasons. After all, the best act from the aesthetic point of view still seems to be to save the painting rather than the guard. Thanks to an anonymous referee for helpful discussion here.

${ }^{23}$ Another way in which we might make this point is to say that, in comparison to morality, aesthetics is more concerned with valuations than deliberative judgements. In other words, aesthetics is more concerned with judgements about aesthetic goodness or value than aesthetic oughts or musts. I borrow this distinction from Wiggins (1987 p.95). In these terms, my point is that while aesthetics may be less concerned with oughts than morality that we do nevertheless make aesthetic practical judgements. Thanks to an anonymous referee for helpful discussion here.
} 


\section{Forthcoming in Inquiry}

point of view of the producer rather that the audience of art and music. ${ }^{24}$ When a painter makes a judgement as to the right colour for her to use or a jazz musician decides what is the right note to play it may seem more plausible to think that many of the aesthetic judgements being made will be first personnel practical ones. Even some aesthetic judgements made from the position of the audience might be directly action guiding. For example, if I am the judge of a competition for novelists then my judgement that I have most aesthetic reason to award it to Novel $\mathrm{X}$ rather than Novel $\mathrm{Y}$ will be a first personal judgement. ${ }^{25}$ Such cases, though, are rare in comparison to our moral judgements. We are all of us the producers of acts that are open to ethical evaluation and criticism and, as a result, much of our ethical language and discourse is concerned with the evaluation of our own behaviour. If we accept Normative Internalism then this provides us with an additional explanation for the intuition that Moral Internalism is more plausible than Aesthetic Internalism. The reason that this is the case is that moral judgements are more likely to be concerned with what we have first personnel reason to do and it is these judgements that are necessarily connected to motivation. Even those unwilling to accept this claim might concede that aestheticians spend less of their time focusing on these judgements and this would be enough to explain the intuition.

However, we should not assume that this means that aesthetic judgements will never be first-personal all things considered normative judgements. If, for example, I find out that a museum is planning to dispose of a work of art that I judge to be of greater aesthetic value than any other painting I know of and I can save it at absolutely no cost to myself or others then saving the painting is surely what I have most reason to do all things considered. The same point may well apply for the preservation of aesthetically valuable

\footnotetext{
${ }^{24}$ Thanks to Simon Frith for pointing out the importance of these different viewpoints. A similar point is made by Came (2012 p.166).

${ }^{25}$ Thanks to Cain Todd for pressing me on this point and Aaron Meskin for suggesting this example.
} 
natural environments. ${ }^{26}$ In the same way, if an artist is trying to paint a beautiful painting and judges that, of all the available options, a certain brushstroke is the one that would be aesthetically best, then , all else being equal, she surely has most reason all things considered to make that brushstroke.

It is important to note that these reasons to think that a higher proportion of our moral judgements might be of the kind that are necessarily connected to motivation do not give us any reason to think that Moral Internalism is true but Aesthetic Internalism is not. In terms of a necessary connection both kinds of judgement are equal, they will necessarily motivate rational people who do not judge them to be opposed by other stronger or equally weighty normative reasons. The difference then is one of degree rather than a difference in kind. This difference of degree does, though, explain why, at first look, the necessary connection appears more plausible for moral judgements.

To sum up this section, the criticisms made of both Aesthetic and Moral Internalism enable us to see what is wrong with both forms of the view. Internalism is only a plausible claim about judgements concerning what we have all things considered most reason to do. Accepting this form of Internalism allows us to explain why Moral Internalism appears more plausible than Aesthetic Internalism.

\section{Concluding Remarks}

To sum up, in this paper I have responded to three reasons to think that Internalism is a less plausible claim to make about aesthetic judgements than about moral judgements. I have argued that the reason that both criticisms were successful is that they attack an implausible version of Aesthetic Internalism. When we define Moral Internalism in a similar way the same criticisms apply. As a result, these criticisms give us no reason to

\footnotetext{
${ }^{26}$ Thanks to Rob Hopkins for helpful discussion here.
} 
think that Aesthetic Internalism is less plausible than Moral Internalism. I then gave an account of Normative Internalism that can avoid both of these objections. On this account, moral and aesthetic judgements are connected to Internalism in exactly the same way; whenever these judgements are also first personal all things considered normative judgements they will motivate rational agents. However, there does seem to be reason to think that moral judgements might meet these criteria more often than aesthetic judgements.

I started this paper by asking whether aesthetic judgements are cognitive or noncognitive states and set out to investigate whether an aesthetic non-cognitivist could appeal to Aesthetic Internalism in order to support her view. I have argued that there is a sense in which Internalism is true for aesthetic judgements, it is true for rational agents when such judgements are also first personal judgements about what there is most reason to do all things considered. However, it is far from clear that this version of Internalism is one that provides much support for the non-cognitivist, if any. After all, the cognitivist can argue that this restricted form of Internalism, if true, tell us something interesting about what it is to be a rational agent rather than anything interesting about aesthetic or moral judgements. ${ }^{27}$

As I have already mentioned, the form of Internalism that I laid out in the final section of this paper does not explain why it seems strange for Alex to be unmotivated by his aesthetic judgement in Case 2. However, if there is a connection between this judgement and the all things considered normative judgement then this might explain why this case seems strange. Such a connection might be a necessary one or perhaps one that can be

\footnotetext{
${ }^{27}$ Similar points are made by Enoch (2011 p.251), Miller (2008 p.252) and Svavarsdóttir (1999 p.183) against forms of Moral Internalism restricted to rational agents. Given that Normative Internalism is restricted to both rational agents and to first personal judgements about what there is most reason, all things considered, to do it seems reasonable to think that the point is even more pertinent here.
} 
explained by pragmatics. The investigation of whether there is any such connection and what kind of connection it might be is, to my mind at any rate, one that is worthy of further investigation. ${ }^{28}$

\section{Bibliography}

Archer, Alfred. 2014. "Moral Rationalism Without Overridingness,” Ratio 27 (1): 100114. doi:10.1111/rati.12023

Archer, Alfred. 2016. "Motivational Judgement Internalism and the Problem of Supererogation" Journal of Philosophical Research 41: 601-621. doi: 10.5840/jpr201681787

Aristotle 1953 Nicomachean Ethics Translated by J. A. K. Thomson. London: Penguin.

Ayer, A. J. 1936 Language, Truth and Logic. London: V. Gollancz, Ltd.

Blackburn, Simon. 1998. Ruling Passions: A Theory of Practical Reasoning Oxford: Oxford University Press.

Bonzon, Roman. 2009 "Thick Aesthetic Concepts." The Journal of Aesthetics and Art Criticism 67 (2): 191-199). doi: 10.1111/j.1540-6245.2009.01348.x

Budd, Malcolm 2002. The Aesthetic Appreciation of Nature: Essays on the Aesthetics of Nature. Oxford: Oxford University Press.

Came, Daniel. 2012 "Moral and Aesthetic Judgements Reconsidered." Journal of V alue Inquiry 46 (2):159-171. doi:0.1007/s10790-012-9333-1

Chrisman, Matthew. 2007. "From Epistemic Contextualism to Epistemic Expressivism." Philosophical Studies 135 (2):225 - 254. doi:10.1007/s11098-005-2012-3

Dancy, Jonathan. 1993. Moral Reasons Oxford: Blackwell.

Dancy, Jonathan. 2004. Ethics Without Principles Oxford: Oxford University Press.

Dreier, Jamie. 1990. "Internalism and Speaker Relativism.” Ethics 101 (1): 6-26. doi: $10.1086 / 293257$.

Eaton, Marcia Muerlder. 2008. 'Aesthetic Obligations.' The Journal of Aesthetics and Art Criticism 66(1):1-9. doi: 10.1111/j.1540-594X.2008.00283.x

Enoch, David. 2011. Taking Morality Seriously Oxford: Oxford University Press.

\footnotetext{
${ }^{28}$ Thanks to audiences at The 2013 Conference of The European Society of Aesthetics at Charles University in Prague, The 2013 Understanding Value Conference at The University of Sheffield and the 2013 Conference of The American Society of Aesthetics. Thanks to Al Baker, Luke Brunning, David Collins, Joseph Früchtl, Robert Hopkins, Aaron Meskin, Lisa Katharin Schmalzried, Ronald Shusterman, Karen Simecek, Robert Stecker, Cain Todd and Sungwoo Um for their helpful comments. Special thanks to Simon Frith and Giulia Pravato, Christopher Williams and two anonymous referees for helpful comments on early drafts of this paper.
} 
Fairbanks, Sarah Jane. 2012. "A Defense of The Overridingness Thesis.' In Should We Always Act Morally? Essays on Overridingness. Edited by S. Schleidgen. Marburg: Tectum Verlag.

Gibbard, Allan. 2003 Thinking How To Live. Cambridge, MA.: Harvard University Press.

Hampshire, Stuart. 1954 "Logic and Appreciation." In Aesthetics and Language Edited by W. Elton. Oxford: Basil Blackwell.

Hare, R.M. 1952. The Language of Morals Oxford: Oxford University Press.

Hare, R.M. 1968 Freedom and Reason Oxford: Oxford University Press.

Hopkins, Robert. 2001. "Kant, Quasi-realism and the Autonomy of Aesthetic

Judgement." The European Journal of Philosopby 9(2):166-189. doi: 10.1111/1468-

0378.00134

Hume, David. 1757 (1963). “Of the Standard of Taste.” In Selected Essays Oxford: Oxford University Press.

Kieran, Matthew. 2008 "Why Ideal Critics Are Not Ideal: Aesthetic Character, Motivation and Value." British Journal of Aesthetics 48(1):278-294.

doi: $10.1093 /$ aesthj/ayn021

Mackie, J. L. 1977. Ethics: Inventing Right and Wrong London: Penguin.

McDowell, John. 1983. "Aesthetic Value, Objectivity, and the Fabric of the World." In E. Schaper (Ed.) Pleasure, Preference and V alue Cambridge: Cambridge University Press.

McGonigal, Andrew. 2006. "The Autonomy of Aesthetic Judgement." British Journal of Aesthetics 46 (4):331-348. doi: 10.1093/aesthj/ayl019

McNaughton, David. 1988. Moral Vision Oxford: Blackwell.

Miller, Christian B. 2008 “Motivational Internalism.” Philosophical Studies 139(2): 233-255. doi:10.1007/s11098-007-9115-y

Portmore, Douglas. 2011. Commonsense Consequentialism: Wherein Morality Meets Rationality Oxford: Oxford University Press.

Ridge, Michael. 2007. "Expressivism and epistemology: Epistemology for Ecumenical Expressivists." Proceedings of the Aristotelian Society Supplementary Volume 81(1): 83-108. doi: 10.1111/j.1467-8349.2007.00152.x

Ridge, Michael. 2014. Impassioned Belief Oxford: Oxford University Press.

Ross, Stephanie. 2008. "Humean Critics: Real or Ideal?” British Journal of Aesthetics 48(1): 20-28. doi: 10.1093/aesthj/aym042

Saito, Yuriko. 2007. Everyday Aesthetics Oxford: Oxford University Press.

Shafer-Landau, Russ. 2003. Moral Realism: A Defense Oxford: Oxford University Press.

Sinnott-Armstrong, Walter. 2010. "Mackie's Internalism.” In A World Without Values: Essays on John Mackie's Error Theory Edited by R. Joyce and S. Kirchin. Dordrecht: Springer. 
Smith, Michael. 1994. The Moral Problem Oxford: Blackwell.

Stevenson, Charles. 1944. Ethics and Language, New Haven: Yale University Press.

Stevenson, Charles. 1937. “The Emotive Meaning of Ethical Terms.” Mind 46 (181): 1431.

Strandberg, Caj. 2011. "A Structural Disanalogy Between Aesthetic and Ethical Value Judgements." British Journal of Aesthetics 51(1): 51-67). doi: 10.1093/aesthj/ayq025

Stranberg, Caj. 2012. “A Dual Aspect Account of Moral Language.” Philosophy and Phenomenological Research 84(1): 87-122). doi: 10.1111/j.1933-1592.2010.00447.x

Strandberg, Caj. 2013. “An Internalist Dilemma—and an Externalist Solution.” Journal of Moral Philosophy 10(1): 25-51.

Stroud, Sarah. 1998. "Moral Overridingness and Moral Theory." Pacific Pbilosophical Quarterly 79(2): 170 - 189. doi 10.1111/1468-0114.00056.

Svavarsdóttir, Sigrun. 1999. "Moral Cognitivism and Motivation." Philosophical Review 108 (29):161-219. doi: 10.2307/2998300.

Todd, Cain Samuel. 2004 "Quasi-realism, Acquaintance and The Normative Claims of Aesthetic Judgement." British Journal of Aesthetics 44(3): 277-296.

doi: 10.1093/aesthj/44.3.277

Toner, Christopher. 2014. "The Full Unity of the Virtues." Journal of Ethics 18 (3):207227. doi:10.1007/s10892-014-9165-2

Tresan, Jon. 2006. 'De Dicto Iinternalist Cognitivism.” Nô̂s 40 (1):143-165. doi: 10.1111/j.0029-4624.2006.00604.x

Van Roojen, Mark. 2010. "Moral Rationalism and Rational Amoralism." Ethics 120(3): 495-525. doi: 10.1086/652302.

Wallace, R. J. 2006 'Moral Motivation.' In Contemporary Debates in Moral Theory Edited by J. Dreier. 182-195. Oxford: Blackwell.

Wedgwood, Ralph. 2007. The Nature of Normativity Oxford: Oxford University Press.

Wiggins, David. 1987. Needs, Values, Truth. Essays in the Philosophy of Value. Oxford: Blackwell.

Williams, Bernard. 1985. Ethics and the Limits of Philosophy London: Fontana.

Wolf, Susan. 2007. "Moral Psychology and the Unity of the Virtues.” Ratio 20(2):145167. doi: 10.1111/j.1467-9329.2007.00354.x

Zangwill, N. 2008. “The Indifference Argument.” Philosophical Studies 138(1):91 - 124. doi: 10.1111/j.1467-9329.2007.00354.x 